\title{
Evaluation of Air Threshing for Small Lots of Winterfat Fruits
}

\author{
D. TERRANCE BOOTH AND LARRY W. GRIFFITH
}

\section{Abstract}

Alr threshing, using an air gun scarifier, is an improved method for threshing small lots of winterfat [Eurotia lanata (Pursh) Moq.; Ceratoides 1. (Pursh) J.T. Howell] fruits for laboratory analysis. The technique is faster than hand threshing and causes indignificant damage to the seed in contrast to hammer mill threshing which damages about $25 \%$ of the seed.

Winterfat [Eurotia lanata (Pursh) Moq.; Ceratoides 1. (Pursh) J.T. Howell] seed has been removed from its enclosing bracts by threshing in a hammer mill at $500 \mathrm{rpm}$ using a $6.4 \mathrm{~mm}$ screen (Wendall Oaks, USDA-Soil Conservation Service, Los Lunas Plant Materials Center, personal communication, 1979). Stevens et al. (1977) recommended using the hammer mill at $1,000-1,200$ $\mathrm{rpm}$ with a $7.94-\mathrm{mm}$ screen to separate the fruits from the seed

Authors are range scientist and biological technician, respectively, USDA, Agricultural Research Service, High Plains Grasslands Research Station, 8408 Hildreth Road, Cheyenne, Wyo. 82009.

Winterfat fruits (U60-80) were provided by the Utah Div. of Wildife Resources (Wildlife restoration funds W-82-R, Job 1 ). stalks, but their methods are not intended to thresh the seed from the bracts. Booth (1982) and Booth and Schuman (1983) have shown that the bracts which enclose the utricle of winterfat are important adjuncts to seedling establishment and seedling vigor and should not be removed before planting. However, various laboratory procedures require that these bracts be removed. Booth (1984) found that hammer mill threshing damaged or removed that radicle apex and its contributing meristem on $25 \%$ of the seed. The meristematic area, where growth occurs, is also an area in which nutrients and growth regulators are concentrated. For these reasons inaccurate data could result when hammer mill threshed seed is used in germination tests or in an analysis of plant growth factors in the seed. Threshing seed by hand, even with the help of a rubbing board, is a time-consuming and tedious process. Air threshing, using an air gun seed scarifier, was tested as an alternative to hand JOURNAL OF RANGE MANAGEMENT 37(3), May 1984 
or hammer mill threshing of small lots of winterfat fruits. The air gun scarifier was originally designed to enhance germination of small legumes (such as alfalfa) by scratching the seed coat to promote seed imbibition.

\section{Air Gun Scarifer}

The air gun scarifier (Fig. 1) consists of a metal cylinder (3-mm thick walls $\times 115-\mathrm{mm}$ height $\times 100-\mathrm{mm}$ inside diameter) with an uneven inside coating (2-5 mm thick) of silicone rubber (such as Silicone II caulking by General Electric ${ }^{1}$ ) mixed with emory dust.
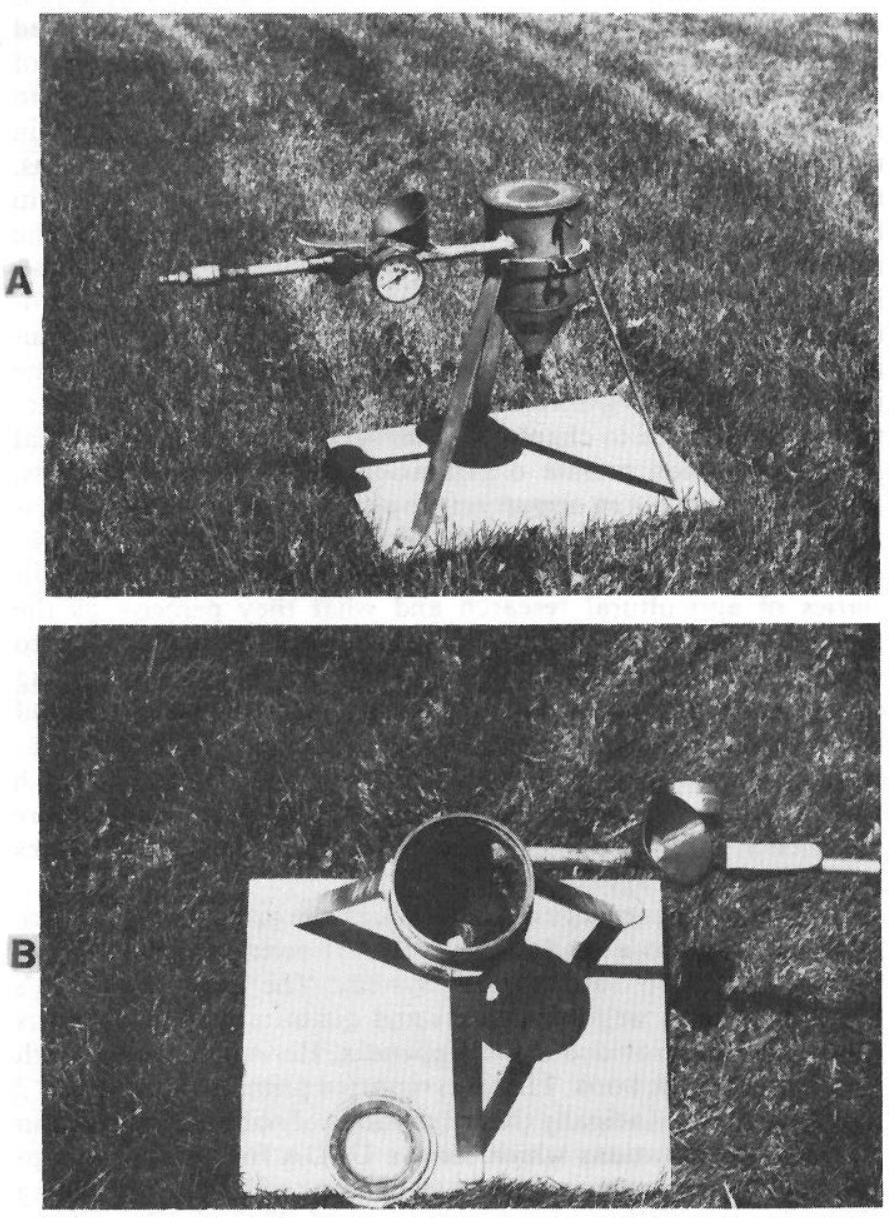

Fig. 1. Side (A) and top (B) views of air gun seed scarifier used for threshing winterfat fruits.

When scarifying seed, this coating holds emory cloth in place in the cylinder. Emory cloth is not used when threshing winterfat. The cylinder is covered by a metal ring machined to fit the top of the cylinder. The ring has a $60-\mathrm{mm}$ diameter center covered by a $1-\mathrm{mm}$ metal screen. This lid is secured by a $6 \times 12-\mathrm{mm}$ wing bolt through

'Use of trade name is for information only and does not imply endorsement of this product over similar material. the side of the cylinder. A metal funnel is permanently attached to the bottom of the cylinder. A pipe (10-mm inside diameter and 150 $\mathrm{mm}$ long) enters the side $30 \mathrm{~mm}$ from the top and offset $35 \mathrm{~mm}$ from the center of the cylinder. An air pressure regulator and gauge, air trigger and air hose coupling, respectively are attached to the distal end of the pipe. A small metal funnel is attached to the top of the pipe at about a $60^{\circ}$ angle and provides an 8-mm diameter opening into it. Winterfat fruits fed into the funnel are shot through the pipe into the cylinder where contact of the fruits against the coated sides separates seeds from the enclosing bracts.

The implement can be easily constructed in a machine shop for about $\$ 100.00$.

\section{Methods}

Winterfat fruits (454 g of selection U60-80) were cleaned of stems and debris then threshed using the air gun at $345 \mathrm{k} \mathrm{Pa}$. Fruit bracts were separated from seeds by passing a light airflow across the seed.

Five samples of 100 seeds were randomly selected from the threshed seed. These were examined microscopically to determine the number of seeds damaged by threshing. After microscopic examination the seed samples were soaked over the weekend at $0 \pm$ $2^{\circ} \mathrm{C}$ (Booth and Schuman 1983), incubated for $21 / 2$ days at $21^{\circ} \mathrm{C}$ for 16 hours and $4.4 .^{\circ} \mathrm{C}$ for 8 hours, then evaluated for positive geotropic response relative to the total germination.

\section{Results and Discussion}

One hour was required to thresh the winterfat fruits. Damaged seed averaged $2.4 \%$ over the 5 replicate samples. Seedlings without a positive geotropic response averaged $3.7 \%$ of the germinated fruits. This compares to $25 \%$ damage and $24 \%$ without a positive geotropic response for hammer mill threshed seed (Booth 1984, Booth and Schuman 1983).

The air gun method is twice as fast as threshing winterfat seed using a rubbing board and yields cleaner seed. The amount of seed damaged by this process is insignificant but might be reduced by increasing the thickness of the silicone rubber coating and by adjusting the air pressure. Air threshing uses tearing stress more than impact to remove the seed coverings. It is an alternate method to be considered for other plant species when impact methods damage the seed. The air threshing method offers a means of obtaining undamaged threshed winterfat seed for laboratory analysis at a low cost relative to hand threshing. It is recommended that the operator use ear plugs and a dust mask when air threshing winterfat.

\section{Literature Cited}

Booth, D.T. 1982. The ecological, physiological and morphological effects of threshing winterfat fruits. In: E.F. Aldon and W.R. Oaks (eds.) Reclamation of mined lands in the Southwest. Soil Conservation Society of America, New Mexico Chapter, P.O. Box 2142, Albuquerque, New Mexico 87102.

Booth, D.T. and G.E. Schuman. 1983. Seedbed ecology of winterfat: Fruits versus threshed seeds. J. Range Manage. 36:387-390.

Booth, D.T. 1984. Threshing damage to radicle apex affects geotropic response of winterfat. J. Range Manage. (In Press).

Stevens, R., B.C. Giunta, K.R. Jorgensen and A.P. Plummer. 1977. Winterfat (Ceratoides lanata). Publication No. 77-2. Utah State Div. of Wildlife Res. 